\title{
Sydslesvig i dag
}

\section{af Jørgen Kühl}

På et informationsmøde om Sydslesvig, som den 1. juni 1996 i forbindelse med årsmødet blev afholdt i Borgerforeningen i Flensborg for bl.a. danske folketingspolitikere, holdt museumsinspektør Jørgen Kühl, Danevirkegården - Museet ved Danevirke, et foredrag om »Sydslesvig i dag«. Det rummede meget tankevækkende betragtninger, som viser, at mindretallet ikke er, hvad det var - eller hvad vi troede det var. Foredraget lagde op til samtale og affødte da også en livlig debat på informationsmødet. Folketingets formand, Erling Olsen, tog foredraget som anledning til sammen med Sydslesvigsk Forening at gennemføre en »høring “ om Sydslesvig, som er berammet til 6. november 1996.

Emnet for de følgende betragtninger er Sydslesvig i dag. Jeg vil her forsøge at påpege og drøfte nogle aktuelle tendenser $\mathrm{i}$ det danske mindretal, som $\mathrm{i}$ mine øjne vil kunne få central betydning for mindretalsarbejdet $\mathrm{i}$ de kommende år. Der vil ikke kunne blive tale om noget omfattende eller detaljeret billede af dagens Sydslesvig. En sådan analyse ville munde ud i et digert værk. I stedet vil der her blive fokuseret på udvalgte sider af mindretallets aktuelle vilkår. Jeg har valgt at inddele beskrivelsen i fire punkter: Først bliver forholdet mellem mindretallet og politikken drøftet, dernæst forholdet mellem dansk forskning og mindretallet, så mindretallet og kulturen; endelig gives der et gisnende bud på, hvorledes mindretallets fremtid kunne tænkes at forme sig.

\section{Mindretal og politik}

For øjeblikket synes det, som om én af de centrale faktorer, der er med til at bestemme det danske mindretals image udadtil, er det politiske område. Det hænger naturligvis sammen med den store succes ved de seneste to politiske valg: kommunevalget $i$ foråret 1994 samt delstatsvalget i foråret 1996. I begge tilfælde var der tale om en massiv stemmefremgang til i hvert tilfælde godt 38.000. På mandatsiden betød valgresultatet henved 160 medlemmer i de kommunale råd samt to medlemmer i landdagen i Kiel. Det var godt 50 flere end ved kommunevalget 1990 og en fordobling af landdagsgruppen. Der kan således tales om en politisk succes, som der med rette er blevet taget notits af. Vi skal tilbage til 1950 erne for at kunne registrere tilsvarende gode valgresultater. Mindretallet synes med andre ord at stå stærkt for øjeblikket. Således forekommer det i det mindste, når den politiske konjunktur lægges til grund for vurderingen. 
Imidlertid er den politiske konjunktur næppe velegnet til at danne sig et indtryk af mindretallets faktiske status. Meget taler nemlig for, at der her $\mathrm{i}$ 1990erne for første gang i mindretallets historie efter 1945 ikke længere findes nogen direkte sammenhæng mellem de kulturelle og politiske konjunkturer i Sydslesvig. Fremgangen på det politiske område følges i disse år ikke af en tilsvarende vækst i medlemstallet i de kulturelle foreninger. Den gunstige politiske konjunktur kan således heller ikke ses som udtryk for en stærk, endsige ekspansiv danskhed i Sydslesvig.

Det politiske parti SSW har utvivlsomt ydet et stort og godt stykke arbejde på alle niveauer i Sydslesvig samt ikke mindst i landdagen. Det er blevet honoreret ved, at mange folk i de seneste valghandlinger har sat deres kryds ud for netop SSW. Det har der været mange grunde til. Grunde, der for en stor del af stemmetilvækstens vedkommende dog næppe isoleret kan udlægges som nationale motiver.

Efter kommune- og delstatsvalget blev der meget kort i offentligheden gjort forsøg på en analyse af valgresultaterne. ${ }^{1}$ I den forbindelse syntes det, som

Sammenlignes SSWs stemmetal ved landdagsvalgene i Slesvig-Holsten siden 1947 med SSFs medlemstal $i$ de samme dr, fremgdr det, at der siden midten af 1980erne har varet tale om to modsatrettede udviklingstendenser for hhv. det politiske partis og den store kulturelle forenings vedkommende. Mens politisk stemme- og kulturelt medlemstal fulgtes ad $i$ deres konjunkturer fra $1950 \mathrm{og}$ frem til landdagsvalget $i$ 1983, skete der en markant opsplitning af de politiske og kulturelle konjunkturer for det danske mindretal og de nationale frisere $i$ midten af 1980erne. I 1987 kunne SSW oge sit stemmetal ved landdagsvalget sammenlignet med det foregdende valg. SSF måtte derimod notere et fald i medlemstallet. Ved de folgende landdagsvalg fortsatte SSW' stemmefremgang, mens SSF i de samme ar hver gang mátte registrere en nedgang i medlemstallet. I 1996 la SSWs stemmetal pd mere end det dobbelte af SSFs medlemstal.

Forskellen medllem de to konjunkturer kan tolkes således: SSWs stemmefremgang skyldes formentlig dels, at et voksende antal valgere har fundet sympati for SSWs politiske malsatninger og derfor stemmer pd partiet, mens en del af stemmefremgangen desuden kan antages at hidrore fra proteststemmer mod de etablerede politiske partier i Slesvig-Holsten. Den positive politiske konjunktur resulterer ikke i nogen aget tilslutning til SSF. Som sådan er der overvejende tale om en politisk identifikation med mindretalspartiet, mens en kulturel identifikation med det danske mindretal ikke finder sted. Mindretallets kulturelle konjunktur nyder således ikke godt af den politiske stemmefremgang. men mả konstatere et fortsat, stot fald $i$ sin medlemstilslutning.

Den politiske opbakning befinder sig $i 1996$ pd niveau med stemmetallet $i$ 1954, da SSW i ovrigt fik farre stemmer ved landdagsvalget, end der pd samme tid fandtes af medlemmer $i$ SSF og de nationale friseres forening. SSFs og Foriining for nationale Friiskes samlede medlemstal ligger imidlertid $i 1996$ pd nasten en tredjedel af medlemstallet $i 1954$.

Medmindre der siden 1980erne har varet tale om en udviklingsproces, hvori folks tilhorsforhold til mindretallet stadig mere udpraget er blevet reduceret til en politisk valghandling til gavn for mindretallets politiske parti, ma det konstateres, at den politiske fremgang ikke er udtryk for mindretallets kulturelle styrke.

Der er saledes grund til at vare opmarksom pd den fortsatte udvikling af de politiske og kulturelle konjunkturer, idet de vil fa afgørende indflydelse pd mindretallets fremtidige struktur og organisationers funktion. Endelig skal det understreges, at der ikke er tale om nogen pludseligt opstdet forskel mellem de to konjunkturer, men der er tale om udviklinger, som har fundet sted over en tidrig periode. 
om man - forståeligt - havde svært ved klart at vedgå, at stemmefremgangen ikke er identisk med mindretallets fremgang. Det danske mindretal står hverken i numerisk eller kulturel eller sproglig henseende stærkere, end det gjorde for 5 år siden. Fremgangen på det politiske område er nemlig ikke blevet fulgt op af en tilsvarende fremgang på det kulturelle område. Tværtimod falder medlemstallene i de kulturelle foreninger fortsat. Der er samtidig intet, der tyder på, at mindretallet er blevet markant større.

Det er næppe sandsynligt, at samtlige $\mathbf{3 8 . 0 0 0}$ satte deres kryds ved SSW, fordi de nærede sympati for eller identificerede sig med det danske mindretal. Mange har sikkert stemt på SSW, fordi de kunne identificere sig med dets politiske program. Atter andre har givetvis stemt på SSW for at udtrykke deres protest imod de andre partiers politik. Det er nødvendigt at understrege,

\section{SSWs stemmetal og SSFs medlemstal i årene for} landdagsvalgene i Slesvig-Holsten 1947-1996

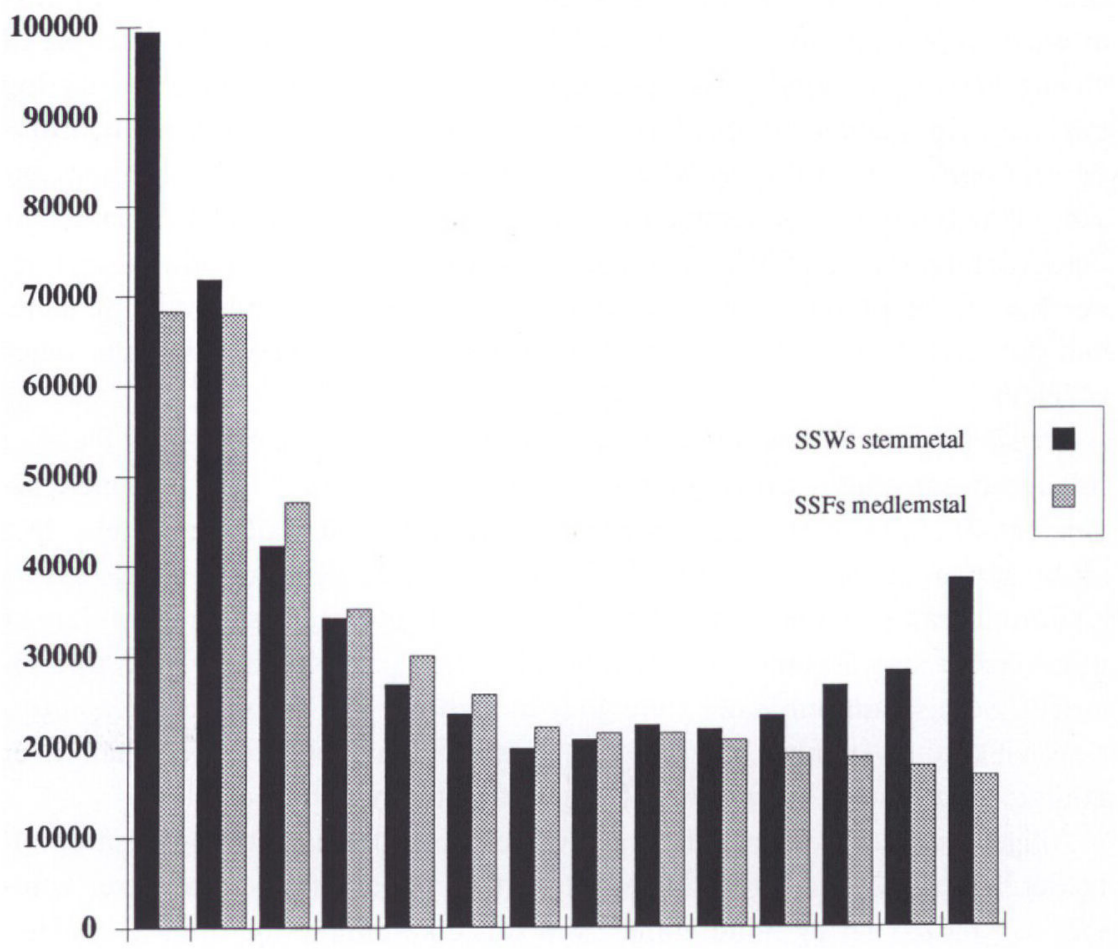

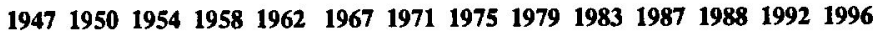
Note: SSFs medlemstal er inklusive Foriining for nationale Friiske. 
at der har været tale om politiske valg, men ikke om nogen folkeafstemning, der har udsagnskraft for sindelagsfordelingen i Sydslesvig. Tidligere kunne der antages en nogenlunde overensstemmelse mellem vælgeradfærd og nationalt tilhørsforhold. Således er det næppe længere i 1990erne. Det forekommer derfor urimeligt at tage alle SSW-vælgere til indtægt for danskheden. I så fald ville der nemlig være sket et revolutionært bevidsthedskifte fra den ene dag til den anden: Hvis mindretallet i 1990 med 23.000 stemmer talte 50.000 personer, så måtte det i 1994 og i 1996 med 38.000 jo tælle mindst 75.000. Det er der dog intet, der tyder på - og da slet ikke, hvis man ser på de sydslesvigske danske organisationers medlemstal. Her er der tværtimod - med kirken som bemærkelsesværdig undtagelse ${ }^{2}$ - mestendels tale om stagnation eller moderat nedgang. ${ }^{3}$

Man kan altså næppe komme uden om at konstatere, at forholdet mellem mindretallet og politikken i dag er et andet, end det traditionelt har været. Det hverken kan eller skal man dog laste SSW for. Tværtimod har partiet jo haft succes med at etablere og markere sig som vægtig faktor i det politiske landskab i Slesvig-Holsten. Det har igen ført til, at der også er blevet taget notits af partiet og af mindretallet $i$ andre dele af Tyskland. ${ }^{4}$ At det bl.a. har fort til en karakteristik af mindretalspartiet som et dansk-frisisk regionalparti må dog beklages. Det må stå enhver klart, at partiets legitimation som dansk talerør og vel i øvrigt også selve grundlaget for, at det er fritaget for 5\%-spærregrænsen - ikke ligger $i$, at det defineres som regionalt parti, men udelukkende i, at det er det danske og frisiske mindretals politiske parti. Som mindretalsmenneske kunne jeg tit ønske mig, at denne side var blevet fremhævet lidt mere, end det faktisk og sikkert ud fra logiske valgtaktiske overvejelser har været tilfældet.

Ikke desto mindre må det samtidig fremhæves, at det danske (og det frisiske) mindretal naturligvis nyder godt af SSWs politiske succes, idet stemmefremgangen har skabt større opmærksomhed omkring mindretallets eksistens. Det vil forhåbentlig igen kunne føre til, at der tages yderligere nødvendige skridt på kommunalt plan hen i retning af økonomisk ligeberettigelse og ligestilling af mindretallet med flertallet. Mindretallets politiske parti står i dag altså formelt stærkt. Som sådan burde der være gode muligheder for, at mindretallets interesser vil kunne varetages bedre og langt mere effektivt, end det hidtil har været muligt, da der nu er større politisk vagt bag argumentationen.

Alligevel er der nok grund til at overveje, om det nu vitterlig også er tilfældet. Spredte oplysninger kunne således tyde på, at succesen måske er kommet bag på partiet og mindretallet. Ved sidste kommunevalg opnåede partiet så stor en fremgang, at folk, der opstillede ud fra loyalitet, men samtidig med forventning om, at de næppe ville opnå valg, pludselig var i den situation, at 
de måtte varetage et politisk hverv. Det kom åbenbart bag på mange, der af sikkert helt legitime grunde slet ikke havde overskud eller tid til at arbejde $\mathrm{i}$ de politiske răd. Nogle mennesker sagde fra. Senest er det i foråret 1996 sket i Lindeved kommune, hvor det ikke var muligt for SSW at finde nogen, der var villige til at overtage den vakante plads i byrådet, efter at én af de oprindeligt valgte opgav sit mandat - og som konsekvens deraf mistede SSW sin fraktionsstatus.

Det er naturligvis en yderst uheldig udvikling. Den kan næppe undgå at få konsekvenser blandt vælgerskaren, der forståeligt vil kunne føle sig holdt for nar og måske vil tænke sig om en ekstra gang, førend de næste gang sætter deres kryds ud for et parti, hvor de opstillede kandidater åbenbart ikke kunne eller ville tage imod valg. Samtidig skal det dog understreges, at dette ikke er nogen kritik af SSW. Tværtimod gør partiet jo sit yderste for, at mandatfremgangen kan omsættes til reel politisk indflydelse og kontant udbytte for mindretallets arbejde.

Nej, i grunden er SSWs vanskeligheder ved at få folk til at påtage sig politiske hverv ikke grundlæggende forskellige fra andre partiers. Den eneste forskel er jo nok den, at der er et større kandidatpotentiale blandt de store partier, end det er tilfældet hos SSW. Samtidig skal det fremhæves, at netop SSW i kraft af sin egenskab som mindretalsparti kan mønstre en langt større medlemssolidaritet og loyalitet end hovedparten af de tyske partier. Og det er vel netop denne dybe loyalitet over for mindretalspartiet, der i sidste ende er grunden til, at nogle har set sig nødsaget til at sige fra, da valgresultatet først forelå. De opstillede i kraft af deres loyalitet. De regnede ikke med at opnå valg.

Ikke desto mindre er der alligevel grund til at overveje, hvilke konsekvenser der kan udledes af dette sikkert ikke faretruende, men alligevel bemærkelsesværdige fænomen. For det egentlige problem er vel spørgsmålet om, hvorledes det kan sikres, at der inden for mindretallet også fremover findes mennesker, der er villige og har overskud til at påtage sig tillidshverv. Det gælder såvel inden for det politiske som inden for det kulturelle område. For det er jo netop ikke noget fænomen, der begrænser sig til SSW. Også inden for det kulturelle arbejde og i ungdomsforeningerne er det stadig vanskeligere at finde folk nok, der er villige til at påtage sig det ofte besværlige og i hvert tilfælde tidskrævende bestyrelses- og tillidsmandsarbejde.

Det gælder altså kernen i det folkelige arbejde. Det er det frivillige bestyrelsesarbejde, som udgør fundamentet for mindretallets folkelige virke. Erfaringerne inden for det politiske arbejde må som sådan tages som et signal om, at det er på tide at tage dette forhold op til overvejelse. Og det sker da også i mange sammenhænge, hvor det er blevet påpeget, at der er problemer med 
basisarbejdet. Problemer, der er blevet drøftet seriøst, og som sikkert vil skulle drøftes endnu mere i de kommende år.

I den forbindelse er det vigtigt at fremhæve, at mindretallet $i$ denne henseende er mindre udsat end flertalsbefolkningen er det. De store tyske foreninger har således også svært ved at mobilisere folk, der vil påtage sig frivilligt arbejde. De har endog ulige større vanskeligheder ved at mobilisere tillidsmænd, end mindretallet har, idet der $i$ det danske mindretal stadig findes en stærkt udpræget solidaritetsfølelse. Alligevel må det dog påpeges, at det tit er Tordenskjolds få soldater, der i mange sammenhænge i dag bærer det danske foreningsarbejde videre. Det er de selvsamme mennesker, der er politisk aktive, sidder i bestyrelserne for SSF-distrikterne, er med i ungdomsforeningerne samt danner menighedsrådene.

Hermed er vi så tilbage ved udgangspunktet for punktet mindretallet og politik: For det er et beklageligt faktum, at stemmefremgangen intet har ændret i positiv retning for mindretallets indre struktur. De mange ny stemmer har ikke ført til mange ny aktive mennesker i det danske mindretalsarbejde. Det er overvejende de samme mennesker, der nu har påtaget sig endnu mere arbejde til gavn for mindretallet. Og deres antal vokser ikke. Det falder stødt ikke mindst, fordi der mange steder også mangler unge, der er villige til at tage over, når de ældre falder fra.

\section{Det danske mindretal og dansk forskning}

I de seneste år er det danske mindretal ved forskellige lejligheder blevet genstand for danske forskeres interesse. I første omgang var det den kendte kulturforsker, nu Jean Monet-professor i europæisk civilisation, Uffe Østergård fra Aarhus Universitet, der siden 1994 har gjort sig bemærket ved i flere forskellige sammenhænge at fokusere på mindretallet. Det skete i forste omgang i form af en artikel i Information i juli 1994, der var anledning til, at Borgerforeningen i Flensborg inviterede ham til i slutningen af februar 1995 til at holde et foredrag om sit syn på Sydslesvig. Han gjorde i den forbindelse bl.a. opmærksom på, at et stigende antal folk uden traditionel tilknytning til mindretallet betjener sig af mindretallets institutioner. Desuden talte han for, at mindretallet bør forsøge at blive uafhængig af tilskuddene fra Danmark. ${ }^{5}$ Han gjorde det på sin velkendte provokerende facon, der da også øjeblikkeligt afstedkom voldsomme reaktioner fra sydslesvigsk mindretalshold. Således skrev Flensborg Avis en hel leder $i$ anledning af Uffe Østergårds betragtninger, der $i$ en absolut afvisende og negativ tone blev karakteriseret som "misforståelser og usagligheder om Sydslesvigs danske folkedel ${ }^{6}{ }^{6}$ Andre folk i mindretallet 
følte sig ligeledes misforstået og fejlfortolket. Diskussion efter foredraget viste, at en del danske sydslesvigere faktisk opfattede Uffe Østergårds udsagn som et angreb på mindretallet. Og dét til trods for, at Uffe Østergård ifølge egne udsagn faktisk nærer sympati for mindretallet. En mere nøgternt betragtning vil i øvrigt vise, at der slet ikke var tale om noget frontalangreb på mindretallet, men derimod om et forsøg på en nytolkning af det danske mindretal som del af en slesvigsk størrelse set i lyset af bl.a. europæiske regionaliseringstendenser. Men dén pointe gik helt og aldeles tabt i forargelsen. I et helt andet forum kommenterede Uffe Østergård postyret således: „I al beskedenhed har jeg selv det sidste års tid været udsat for professionelle sydslesvigsk-danskes intolerance over for nye meninger på området. Der hersker en beslutsom mangel på accept af, at også andre kan vide noget om regionen«. ${ }^{7}$ Dén vurdering blev dog ikke refereret i Sydslesvig.

Tilsvarende afvisende og negative sydslesvigske reaktioner kom i kølvandet på en anden dansk forskers udsagn. Henrik Becker-Christensen, der er direktør for Grænseforskningsinstituttet i Aabenraa, advarede midt i maj måned $1996 \mathrm{i}$ en vurdering af SSWs resultat ved delstatsvalget om, at SSWs stemmefremgang måske kunne blive et problem for mindretallet, da der jo realistisk set ikke var tale om overvejende danske stemmer. Han påpegede $i$ en udtalelse til Ritzaus Bureau, at der ad åre var fare for, at de danske $\mathrm{i}$ SSW kunne gå hen at blive et mindretal. En fortsat øget regionalt motiveret tilslutning til SSW ville måske på et tidspunkt også kunne »blive et problem i forhold til de bevilgende myndigheder i Danmark, som man er helt afhængig af « ${ }^{8}$ Udsagnene blev omgående afvist af forskellige fremtrædende SSW-skikkelser, altimens SSWs formand bevidst undlod at kommentere artiklen desangående. SSW-landsstyrelsesmedlemmet Sven Engel fastslog derimod meget kategorisk, at wvi igen bliver konfronteret med en rigsdansk ekspert, der tilsyneladende ikke har særlig meget forstand på forholdene $\mathrm{i}$ grænselandet«. Og han fortsatte: "Gad vide, hvordan forskeren skelner mellem danske og tyske vælgere, eftersom kun tyske statsborgere har stemmeret til landdagsvalget. Folks holdninger, identitet og motivering i stemmeboksen kan vel næppe granskes«. Flensborg Avis valgte at opsummere denne vurdering i overskriften: "SSW: En dansk forsker på vildspor«. ${ }^{9}$ Samme dag tog avisen stilling til Becker-Christensens refererede udsagn $i$ en leder, som fastslog, at der var tale om en "spinkel forskerteori ${ }^{10}{ }^{10}$ Endnu engang havde en dansk forsker åbenbart rørt ved et tabu. Og endnu engang reagerede nogle i Sydslesvig på en i grunden kontraproduktiv facon.

Problemet ved, men samtidig karakteristisk for de her refererede - og andre uformelle - reaktioner fra folk i det danske mindretal på rigsdanske forskerudsagn var, at de to sider talte forbi hinanden. Forskernes vurdering blev ikke 
opfattet som dét, de var - nemlig forsøg på analytisk at påpege aktuelle tendenser og mulige fremtidige konsekvenser. I stedet for at tage disse udsagn op til en reflekteret og kritisk drøftelse, nøjedes man med at reagere fornærmet og ved omgående at mistænkeliggøre forskernes motiver. I stedet for at fremføre underbyggede modargumenter, der kunne påpege eventuelle misforståelser eller skævheder i vurderingerne, blev forskerne dømt og fik påskrevet uvidenhed. På den måde undgik man dog samtidig at skulle tage begrundet stilling til indholdet $\mathrm{i}$ de fremførte forskerudsagn. Det kom der naturligvis ingen konstruktiv dialog ud af.

Disse reaktioner på danske forskeres analyser kan tolkes som symptomatiske for en sydslesvigsk modvilje over for at se mindretallet $i$ et andet perspektiv end det vante. Dét, som mindretallet i de seneste år ved forskellige lejligheder er blevet konfronteret med, er et fænomen, som kan forventes at spille en større rolle i fremtiden. I og med, at den generelle interesse for mindretalsspørgsmål er vokset efter de politiske omvæltninger i Østeuropa, er der efterhånden også vokset en større interesse for det dansk-tyske grænseland. Mens kulturforskerne tidligere slet ikke interesserede sig for grænselandet, har det ændret sig i de seneste år. Mindretal er in. Og det danske mindretal er også så småt blevet interessant at beskæftige sig med for folk, der i årevis har ignoreret den kompetente forskning, der er blevet gjort i Sønderjylland.

Den dansk-tyske grænseregion omtales i dag som europæisk mindretalsmodel og har givet anledning til en række problematiserende betragtninger. I den forbindelse er der også blevet givet udtryk for egne ungdomsoplevelser med mindretallet, der øjensynligt ikke har efterladt noget positivt indtryk. Det gælder således den kendte antropolog Anne Knudsen, der i en debatartikel om Slesvig som skoleeksempel husker sit møde med Sydslesvig således: "På skolens ekskursion til Sydslesvig oplevede vi det danske mindretals professionelle talsmænd som fanatikere med vilde øjne «. " Sådanne personlige oplevelser spiller imidlertid næppe nogen rolle for, at ny generationer fatter interesse for grænselandet. De har som regel aldrig før hørt om det danske mindretal. Det er derimod inspireret af mindretalsproblematikkens generelle aktualitet i Euro$\mathrm{pa}$, at de pludselig får øjnene op for det dansk-tyske grænseland. Flere og flere studerende ved danske, men såmænd også tyske universiteter og på seminarierne er således $\mathrm{i}$ de seneste år begyndt at skrive projektopgaver og specialer om Sydslesvig. Det sker ikke ud fra den klassiske, folkelige interesse for det danske syd for grænsen, men er primært videnskabeligt hhv. fagligt begrundet.

Denne ny interesse for Sydslesvig er altså i dag motiveret ud fra en forskningsinteresse, der igen vil kunne udgøre en intellektuel udfordring af mindretallet. Forskerne stiller andre spørgsmål og er mere kritiske i deres tilgang til emnet, end mindretallet traditionelt har været vant til fra danskere nordfra. 
Forskerne nøjes ikke med at glæde sig over, at der findes en danskhed syd for grænsen, som viser Dannebrog og holder fast i danske udtryksformer, som efterhånden er ved at forsvinde i Danmark. De vil i stedet vide hvorfor, hvordan og hvorledes den danske identitet holdes i hæud. Og de vil vide, hvem og hvad mindretallet er. Derfor kræver de også en anden slags svar, der honorerer deres metode, og som kan give begrundede svar på begrundede spørgsmål. De er ikke tilfredse med generelle udsagn, men ønsker en præcis og ræsonnerende karakteristik. Undertiden kan det være vanskeligt for mindretallet at forholde sig til denne ny interesse, fordi den til dels kan virke slående og overraskende, måske til tider ligefrem intimiderende. Der er her behov for en anden slags dialog end den, man har været vant til. I sig selv er det naturligvis positivt, at forskere og studerende - samt journalister - viser interesse for Sydslesvig; men på den anden side findes der samtidig en frygt for at blive misforstået, fejlfortolket og i yderste konsekvens misbrugt.

Jeg tror med andre ord, at vi må sande, at der vil blive tale om en intellektuel udfordring af mindretallet. Hvor det hidtil har være den folkelige solidaritetsfølelse, der har båret store dele af den danske befolknings interesse for hhv. villighed til at støtte det danske mindretal - så vil vi i den nærmeste fremtid sikkert i stadig mere udpræget grad konfronteres med danske intellektuelles refleksioner omkring mindretallet. Det er allerede sket i flere sammenhænge. Det vil afgjort blive tilfældet igen i den kommende tid. Legitimationspresset udefra vil uvægerligt og nødvendigvis føre til en perspektiverende refleksion af mindretallet i mindretallet.

I Sydslesvig er vi realistisk talt for tiden ikke rustet til en sådan ny udfordring. Vi er ikke vant til at betragte os selv intellektuelt. Vi opfatter os selv som unik størrelse og lukker derfor ofte øjnene for sammenligninger med andre kulturelle grupper. Mindretallet er måske i virkeligheden negativt indstillet over for intellektuelle tilgange, fordi de i mange henseender bryder med vores traditionelle folkelige opfattelse.

Ikke desto mindre vil jeg mene, at der fremover vil finde en intellektualisering sted i mindretallet. Det vil føre til en anden diskussion, end den hidtil er blevet ført. Mindretallet vil sikkert skulle nytænkes. Der vil givet blive brug for en anden slags terminologi, der karakteriserer mindretallet ved begreber som konjunkturer og processer, assimilation og dissimilation, interaktion, integration og segregation, frem for som hidtil udelukkende at betragte mindretallet som en især folkeligt-nationalt defineret størrelse. Men det vil sikkert også kunne føre til en ny forståelse mellem intellektuelle i Danmark og i mindretallet. Intellektualiseringen af mindretallet betinges dog af udviklingen af et akademisk uddannet potentiale i mindretallet. Det findes til dels allerede - blot ikke i Sydslesvig, men i Danmark og i andre dele af Tyskland, hvor arbejds- 
pladserne findes. Heri ligger der en stor opgave for mindretallet, som vil kunne blive vanskelig at løse.

\section{Mindretallet og kultur}

Sidste år var jubilæumsåret, hvor der var rig lejlighed til at se tilbage og forsøge at forstå det danske mindretal i en historisk dimension. I den forbindelse blev ikke mindst det tætte samhørighedsforhold mellem det danske mindretal og Danmark fremhæevet og understreget. Det er klart, at det danske mindretal selv i dag vanskeligt kan tænkes uden den store ideelle og materielle støtte, der ydes fra Danmark. Mindretallet er ikke noget mini-Danmark, ingen tro kopi i lilleputformat. Men mindretallet er dybt afhængigt af den rigsdanske kulturelle påvirkning. Mindretallet producerer således kun i meget ringe omfang en egen sydslesvigsk dansk mindretalskultur. Mindretallet reproducerer derimod primært kulturelle strømninger, der gør sig gældende i Danmark, undertiden fortolket ud fra de særlige forhold, der gør sig gældende i grænselandet. Heri er det danske mindretal ikke væsentligt forskelligt fra andre grænselandsmindretal. Det tyske mindretal i Danmark reproducerer ligeledes tysk kultur.

Grundlæggende forskellig er situationen derimod hos de mindretal, der ikke har noget hjemland, de støttes af, og som de kan støtte sig til. De må nødvendigvis producere og skabe deres egen kultur for ikke helt at miste deres nationale og etniske særpræg.

Den danske kultur er grundlaget for det danske mindretal. Den særlige danske identitet $\mathrm{i}$ mindretallet bygger netop på det kulturelle fællesskab med andre danske. Et væsentligt element i den fælles kultur er sproget. Det er igennem det danske sprog, at de forskellige danskheder knyttes sammen. Dansk er mange ting - men fællesnævneren er i hvert tilfælde det danske sprog.

$\mathrm{Nu}$ står vi imidlertid over for det fænomen i Sydslesvig, at der ingen ligefrem overensstemmelse er mellem dét, man abstrakt kan kalde objektive og subjektive kriterier for nationalitet. Sagt konkret betyder dét, at mange i Sydslesvig er danske uden at kunne (i nogle tilfælde endog uden at ville) tale dansk. For mange i det danske mindretal er danskhed en dybt subjektivt defineret størrelse. Danskhed og dansk sprog spiller for dem en mindre rolle. Deres sprog er overvejende tysk. Derimod forbinder de deres danskhed med ikke-sprogligt definerede forhold såsom dansk mentalitet, symbolbrug og først og sidst identifikation med det danske. Anderledes sagt er betydelige dele af det danske mindretal ikke danske, fordi de taler dansk, men fordi de føler sig som og bekender sig til det danske. ${ }^{12}$

Det er et forhold, der er vanskeligt, måske endda umuligt at formidle til 
nogen, der intet førstehåndskendskab har til den særlige mindretalstilværelse. Faktum er nemlig, at det danske mindretal i denne henseende ikke er unik. Tværtimod forholder det sig således, at langt de fleste europæiske mindretal i dag er karakteriseret ved, at identitet og sprog ikke længere er identiske. Sproget er de fleste steder blevet en symbolsk størrelse, der beherskes af en set i forhold til mindretallenes samlede omfang snarest lille skare. Således er forholdene i det danske mindretal dog endnu ikke.

Selv om sprog og identitet således ikke længere opleves som samhørige for store dele af det danske mindretal, skal det dog pointeres, at det ikke er ensbetydende med, at mindretallet ikke længere er dansktalende. Der er stadig centrale dele af mindretallet, hvor dansk sprog og dansk identitet er i overensstemmelse. Derudover bygger grundtanken i alt kulturelt arbejde i Sydslesvig netop

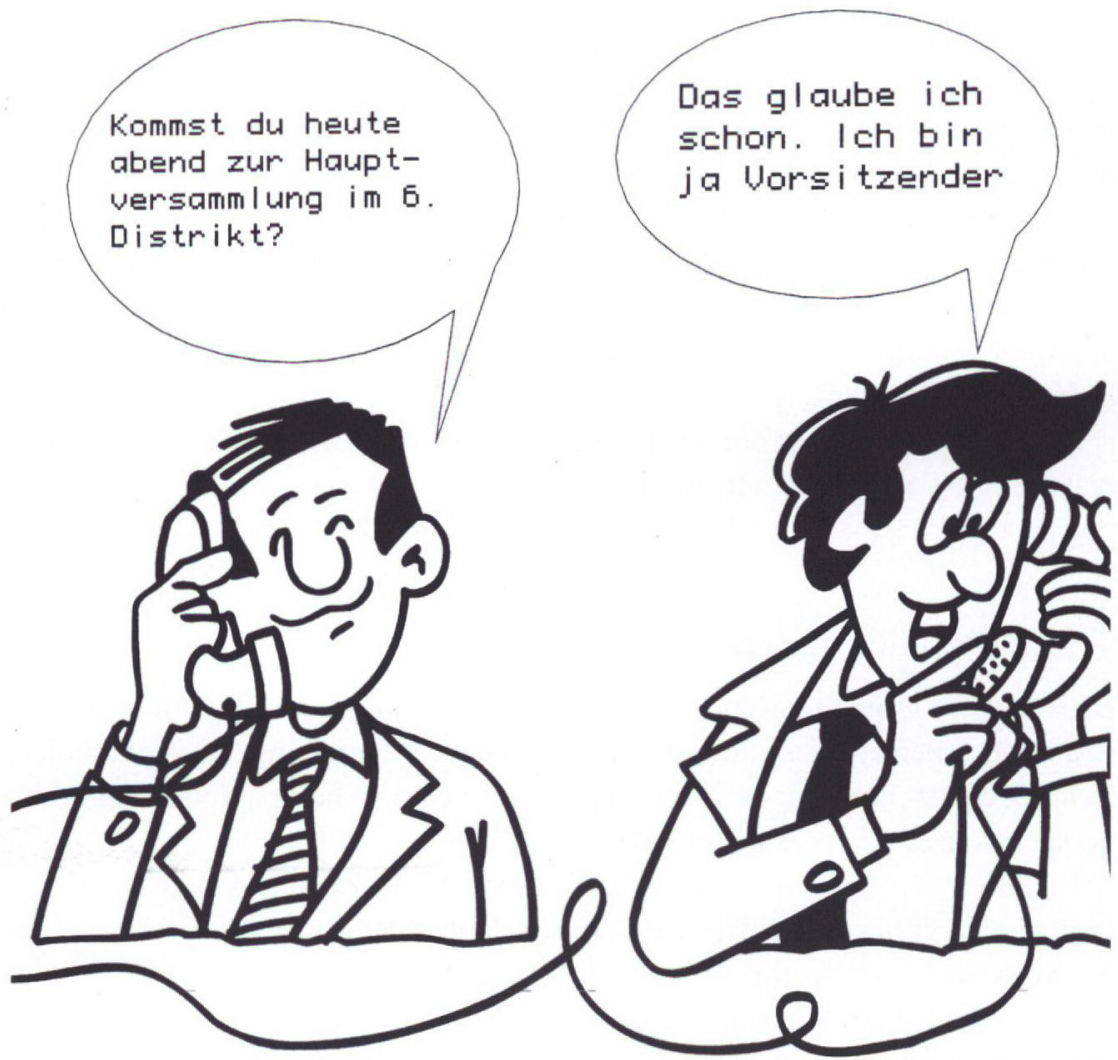

"For mange i det danske mindretal er danskhed en dybt subjektivt defineret storrelse. Danskhed og dansk sprog spiller for dem en mindre rolle. Deres sprog er overvejende tysk". Illustration fra Manfred Kühls kronik i Flensborg Avis 10. februar 1996. 
på, at det danske sprog er grundstammen for mindretalsidentiteten. Især det danske mindretalsskolevæsen indtager her en central position som formidler af det danske sprog, der må anses som et uundværligt redskab ved tilegnelsen af den danske kultur.

Når det er sagt, skal det for tydelighedens skyld fluks tilføjes, at danskhed jo ikke er nogen naturgiven størrelse, men derimod er et produkt af såvel en tilsigtet kulturel prægning som et bevidst valg. Der er ingen i det danske mindretal, der forsøger at fordanske folk mod deres vilje. Derimod bygger al dansk kulturel aktivitet - og dertil hører også skolerne - på den fundamentale antagelse, at de danske organisationer og institutioner naturligvis forsøger at præge elever og medlemmer i dansk retning. En sådan prægning kan dog kun lykkes, såfremt der hos den enkelte og i familierne findes en bevidst identifikation med det danske. Det er denne identifikation, der tilsigtes i mindretallet.

Netop denne sidste del - identifikationen med det danske - er dog, realistisk talt, ikke længere til stede $i$ alle dele af mindretallet. Når man spørger almindelige mindretals-medlemmer om deres nationale tilhørsforhold, så vil man kunne registrere en mangfoldighed af svar, der strækker sig fra den éntydige identifikation som dansk over en regionalt vægtet overgangsidentitet som sydslesviger og helt til den forunderlige udtalelse, at nogle føler sig som tyske med sympati for det danske. Som sådan kan det konstateres, at der ikke findes noget ensartet billede i mindretallet. Mindretallets kultur er dansk; men de individuelle kulturelle udtryksformer er tit præget af sydslesvigske blandingskulturelementer.

Det kan formodes, at der her er tale om en tendens, som vil kunne få større betydning og aktualitet $\mathrm{i}$ de kommende år.

\section{Mindretallet og fremtiden}

Efter således i det foregående at have fremhævet nogle problemstillinger, der er aktuelle, men som samtidig skønnes at have stor betydning for mindretallets fremtid, er det på sin plads afslutningsvis at give nogle bud på, hvilke fremtidsperspektiver det danske mindretal står over for.

Festårets taler blev omkring årsskiftet 1995-96 fulgt op af en række bidrag fra engagerede sydslesvigere, der i en løs kronikserie i Flensborg Avis gav deres bud på, hvordan fremtidsperspektiverne for det danske mindretal i Sydslesvig måtte kunne se ud. ${ }^{13}$ I den forbindelse blev der gjort rede for mange inspirerende tanker, og der blev givet udtryk for synspunkter og opfattelser, som kunne og fortsat kan tæenkes at danne et fortrinligt grundlag for en perspektiverende drøftelse af, hvor det danske mindretal befinder sig, og i hvilken retning det bevæger sig. 
Desværre viste det sig dog, at kronikrækken ikke afstedkom offentlig respons. Ganske vist blev synspunkterne og analyserne drøftet i forskellige uformelle sammenhænge; men nogen egentlig offentlig debat blev det ikke til. Der kom intet formuleret modspil. Hverken i Flensborg Avis eller i andre formaliserede sammenhænge.

Den udeblevne diskussion kan muligvis forklares ved, at jubilæumsåret $\mathrm{i}$ forvejen havde budt på så mange forskelligartede indtryk, at der simpelt hen ikke var overskud til at tage en koncentreret diskussion om, hvad fremtiden måtte indebære. En negativ tolkning af den udeblevne debat kunne dog også udlægges derhen, at der ganske enkelt ingen interesse findes for, hvorledes mindretallet bør indrette sig fremover.

Hvorvidt denne mulige desinteresse skyldes manglen på perspektiver eller en simpelt ulyst til at betragte os selv $i$ en storre sammenhæng og $i$ et perspektiv, der rakker ud over vores umiddelbare, daglige eksistens som mindretal i Sydslesvig, dette spørgsmål er vanskeligt at forholde sig til. Man kan håbe, at det første var årsagen, men samtidig frygte, at det netop var det sidste, som gjorde sig gældende. Uagtet, hvilke motiver der lå bag ikke-diskussionen, var det ikke desto mindre bemærkelsesværdigt, at artikel-forfatterne hver for sig gjorde sig tanker om, hvilke fremtidige udfordringer mindretallet vil blive konfronteret med. Anderledes sagt: En refleksionsproces har fundet sted.

En af de centrale og mest væsentlige udfordringer er sikkert spørgsmålet om, hvorledes mindretallet fremover vil definere og som konsekvens deraf vil udtrykke sin særegenhed i forhold til det omgivende samfund. En nøgtern betragtning vil vise, at der allerede nu ikke længere findes de klare og entydige, umiskendelige og for en stor dels vedkommende også identitetsprægende modsætninger mellem dansk og tysk i Sydslesvig. Tidligere tiders og til dels stadig nulevende generationers personligt erfarede og inderliggjorte konflikt med det tyske er ikke længere relevante for de yngre og unge i mindretallet. Dansk og tysk er kommet hinanden nærmere - men det kan være svært at afgøre, hvorvidt det skyldes mindretallets assimilation til flertallet eller snarest omvendt, at flere og flere fra flertallet er begyndt at søge ind i mindretallet.

I alt fald er det karakteristisk for de seneste års udvikling i mindretallets sammensætning, at der findes flere og flere med en ikke-dansk baggrund. Præcise tal foreligger af gode grunde ikke. Vi kender jo ikke engang det præcise omfang for det danske mindretal som sådan. Men en iagttagelse af tendenserne inden for skoleområdet tyder på, at der er tale om mere end et kuriøst overgangsfænomen.

Åbenbart udøver det danske i dag en meget stor tiltrækningskraft på folk fra det omgivende flertalssamfund. De viser interesse for danske værdier, danske normer og den danske mentalitet. Nogle vælger at gå den danske vej og fravæl- 
ger samtidig deres tyske udgangspunkt. Andre forstår dog at kombinere de to elementer, så deres individuelle identitet så at sige fordobles. De er danske og tyske. Eller tyske og danske.

Noget taler for, at der er tale om en udviklingsproces. Det danske opfattes åbenbart af flere og flere som et reelt alternativ. Ikke blot i politisk henseende, hvor et betragteligt antal af mennesker uden egentligt tilhørsforhold til mindretallet af sikkert mange forskellige individuelle grunde stemmer på SSW. Også på skole- og undervisningsområdet er det danske et alternativ, som en del tyske forældre gerne benytter sig af. Dette valg er dog hyppigt ikke knyttet sammen med noget identitetsskifte. Folk indskoler hyppigt deres børn $i$ de danske institutioner uden $i$ øvrigt at tage konsekvensen ved også at blive aktive $i$ andre dele af mindretallet.

I nogle henseender synes mindretallet altså at blive opfattet som et kulturelt og politisk servicetilbud. Folk uden traditionel tilknytning til mindretallet ja, i nogle tilfælde uden den mindste tilknytning til grænselandet overhovedet benytter sig af de danske tilbud. Som sådan er det danske mindretal øjensynligt blevet til en størrelse, der ikke længere opfattes som en isoleret mængde af mennesker, der bekender sig til dansk sprog og kultur. I dag er den nationale faktors betydning blevet relativeret. Man er ikke længere dansk på samme

\section{Sydslesvigsk Forenings og Foriining for nationale Friiskes medlemstal 1946-1996}

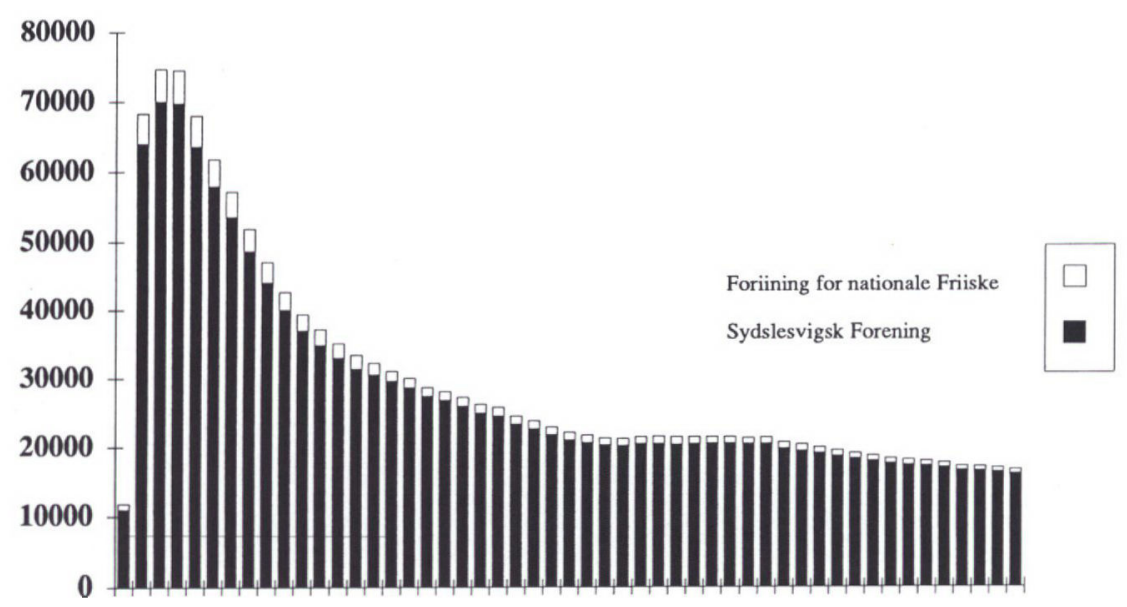

1946-1996

Kilde: Statistikker fra Dansk Generalsekretarial, Flensborg, for årene 1946-1996. 
måde, som det var tilfældet for 20 eller 30 , endsige for 40 og 50 år siden. Det galder ikke mindst på det sproglige område.

Store dele af de nytilkomne forældre tilegner sig nemlig ingen blot elementære frerdigheder i dansk. De forventer tilmed, at der til forældremøder tales tysk til og med dem. Og selv de mennesker, der bliver aktive $i$ andre dele af mindretallet, forventer hyppigt som en selvfølge, at væsentlige arrangementer mindst foregår tosproget på dansk og tysk, men helst udelukkende på tysk. Således har jeg selv i de seneste år oplevet, at jeg - når jeg inviteres ud til at holde foredrag i Sydslesvig - som regel făr at vide, at foredraget forventes at blive gennemført på tysk, selv om det i ét tilfælde endog blev annonceret med en dansk titel.

Den her beskrevne proces synes at fortsætte. Det er en udvikling, der snart vil vise sig at være en udfordring for det danske mindretals selvforståelse. Mindretallet vil uvægerligt blive presset til før eller siden at tage stilling til, hvordan det vil forholde sig over for denne udvikling. Skal de ny mindretalsbrugere opfattes som dele af mindretallet? $\mathrm{Og}$ hvad vil det betyde for mindretallets selvforståelse? Hvilke konsekvenser får det for mindretallets struktur? Vi kan ikke komme uden om at tage stilling til disse spørgsmål.

\section{SSWs stemmetal ved kommune- og landdagsvalgene $i$ Slesvig-Holsten 1946-1996}

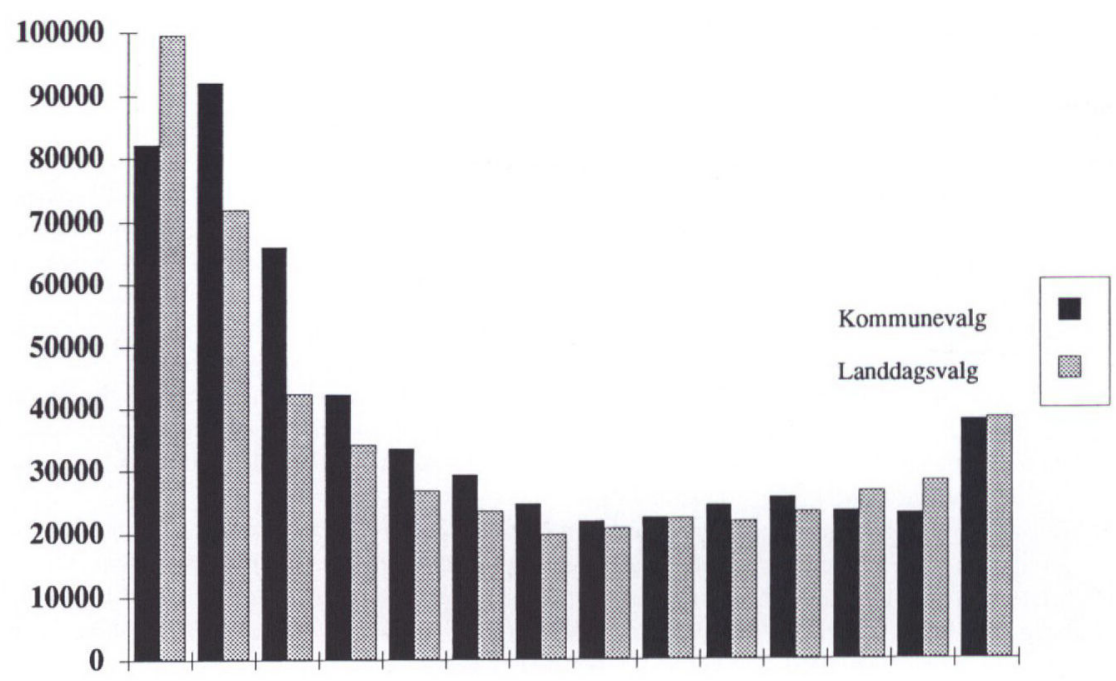

Kommunevalg 1946-94 og landdagsvalg 1947-1996

Kilder: Sydslesvig i tekst og tal, Sydslesvigsk Forening. Flensborg 1994, s. 21; Gransen, 2, juni 1996, s. 6. 
NOTER

1. Se Jørgen Kühl: $N y$ danskere eller protestvalgere? Kommunevalget i Slesvig-Holsten, marts 1994, s. 84-89 i: Sønderjysk Månedsskrift, 5/6 1994.

2. Jævnfør Ole Pedersen: Kristne traditioner atter vardifulde. Dansk Kirke $i$ Sydslesvig fyldte 75 og har trods religies krise i Tyskland et stabilt voksende medlemstal, Grænsen, 2, juni 1996, s. 13.

3. Det gælder ikke mindst for den kulturelle hovedorganisation Sydslesvigsk Forening, hvis samlede medlemstal fraregnet medlemmer af Foriining for nationale Friiske i de seneste år er gået jæunt tilbage: Fra pr. 1.1.1993: 16.463, via pr. 1.1.1994: 16.384 til pr. 1.1.1995: 16.229 medlemmer.

4. Således trykte den store konservativt-borgerlige tyske avis Frankfurter Allgemeine Zeitung (FAZ) en stor, men ikke desto mindre særdeles tendentiøs og på utilstrækkeligt grundlag konkluderende artikel af Friedrich Karl Fromme: Die dänische Minderheit in Schleswig-Holstein genießt einen vielfältigen privilegierten Status, FAZ, 27.3.1996. Denne artikel medførte en række laserbreve i FAZ, heriblandt et læserbrev, som fastslog, at SSW ikke længere blot er et dansk parti, af Christian Glass, Ausacker: Nicht mehr nur eine "Dänenpartei«, FAZ, 4.4.1996. Frommes oprindelige artikel blev gendrevet og kritiseret i Flensborg Avis, hvor den imidlertid ikke blev refereret i sin helhed. Flensborg Avis' leder tilbageviste Frommes udsagn i Bjarne Lønborg: $N y t$ liv til myterne, Flensborg Avis, 28.3.1996. Til gengald var der ingen danske sydslesvigere, der gjorde opmærksom på de mange misforståelser og fejl i selve FAZ. Så FAZs læsere blev aldrig gjort bekendte med den berettigede og nødvendige kritik, der blev rejst i Flensborg Avis over for et indforstået publikum.

5. Uffe Østergård: Sydslesvig tysk, dansk eller slesvigsk", Information, 18.7.1994. Mødet i Borgerforeningen, som blev afholdt på Dansk Centralbibliotek for Sydslesvig i Flensborg, 28.2.1995, forte til en rakke pressereaktioner, bl.a. Jens Høyer: Mindretallet bor frigore sig fra Danmark, Flensborg Avis, 2.3.1995, og Universitetslektor Uffe Østergård: Mindretallet bor droppe tilskud fra Danmark, SSF's medlemsside, Kontakt, Flensborg Avis, 2.3.1995. Disse overvejelser indgår også i Uffe Østergård: Danmark og mindretallene i teori og praksis, s. 44-105 i: Jørgen Kühl (ed.): Mindretalspolitik, Dansk Udenrigspolitisk Institut, København 1996.

6. Bjarne Lonborg: En investering, Flensborg Avis, 9.3.1995.

7. I Uffe Østergård: Granseområderne viser os fremtiden, anmeldelse af Inge Adriansen og Broder Schwensens Fra det tyske nederlag til Slesvigs deling 1918-1920, bogtillægget, Weekendavisen, 18.-24.8.1995, s. 4.

8. Forsker: Mindretallet i mindretal i SSW' Flensborg Avis, 13.5.1996.

9. Raning Krueger: SSW: En dansk forsker pd vildspor. Flensborg Avis, 14.5.1996.

10. Bjarne Lønborg: Spinkel forskerteori, Flensborg Avis, 14.5.1996.

11. Anne Knudsen: Slesvig et skoleeksempel. Granseregioner og mindretal er starkt politisk aktuelle, Fortid og Nutid. juni 1992, hefte 2, s. 173-180, her s. 173. Se også Henrik Becker-Christensen: Litteratur og national identitet $i$ den dansk-tyske granseregion. En kommentar til Anne Knudsens artikel: Slesvig - et skoleeksempel, Fortid og Nutid, december 1994, hefte 4, s. 396-398.

12. Se Jørgen Kühl: Dansk identitet i Sydslesvig, s. 50-67 i: National identitet. Fem foredrag om dansk og tysk identitetsfolelse i granselandet, Institut for Grænseregionsforskning, Aabenraa 1994. Jørgen Kühl: Sprog og identitet i Sydslesvig (1), Sproghjørnet, Flensborg Avis, 22.2.1995, og Sprog og identitet i Sydslesvig (2), Sproghjørnet, Flensborg Avis, 28.3.1996. Se endvidere Jørgen Kühl: På vej mod den slesvigske model. Mindretallene i det dansk-tyske granseland 1955-1995, Institut for Grænseregionsforskning, Aabenraa 1996.

13. Det drejer sig bl.a. om folgende artikler: Kaj Henken: Mindretallet er os selv, Flensborg Avis, 3.1.1996; Lars Erik Bethge: Forhàhentlig en selvedelaggende profeti, I-II, Flensborg Avis, 8.1. \& 9.1.1996; Paul Hertrampf: Stotten til mindretallene og regionens okonomiske trivsel, I-II, Flensborg Avis, 15.1. \& 16.1.1996; Ole Harck: Mindretallet overlever med dansk kultur, Flensborg Avis, 25.1.1996; Manfred Kühl: Det danske sprogs vigtige rolle i Sydslesvig, Flensborg Avis, 10.2.1996. 